\title{
COMPOSITION, DENSITY AND SIZE-STRUCTURE OF THE AUTOTROPHIC PLANKTON COMMUNITY IN A SHALLOW COASTAL ZONE AT KING GEORGE ISLAND, WEST ANTARCTIC PENINSULA (WAP), DURING EARLY SUMMER 2010
}

\author{
BARRERA-ALBA, J.J. ${ }^{1 *}$; TENENBAUM, D.R. ${ }^{2} ;$ VANZAN, M. ${ }^{2} \&$ TENÓRIO M.M.B. ${ }^{3}$
}

1. UNIFESP - Universidade Federal de São Paulo, Depto. Ciências do Mar. Campus Baixada Santista

2. Universidade Federal do Rio de Janeiro, Depto de Biologia Marinha, Instituto de Biologia

3. IEAPM - Instituto de Estudos do Mar Almirante Paulo Moreira, Arrarial do Cabo (RJ)

${ }^{*}$ Corresponding author: barrera.alba@unifesp.br

\begin{abstract}
Barrera-Alba, J.J.; Tenenbaum, D.R.; Vanzan, M. \& Tenório M.M.B., (2015). Composition, density and size-structure of the autotrophic plankton community in a shallow coastal zone at King George Island, West Antarctic Peninsula (WAP), during early summer 2010. Braz. J. Aquat. Sci. Technol. 19(3). elSSN 1983-9057. DOI: 10.14210/bjast. v19n3. The planktonic microorganism community of Admiralty Bay, Antarctic Peninsula is being monitored since 2002. This study describes composition, size-structure and biomass of the phytoplankton communities observed during early summer 2010/2011 in the area. Organisms were counted by microscopy and scored as belonging to three size classes: $<10 \mu \mathrm{m}, 10-80 \mu \mathrm{m}$ and $80-400 \mu \mathrm{m}$. In terms of density, this phytoplankton community was dominated by cells $<10$ $\mu \mathrm{m}\left(\sim 106-107\right.$ cells $\left.\mathrm{L}^{-1}\right)$, confirming the increasing presence of small planktonic autotrophs in West Antarctic Peninsula waters. Organisms $>10 \mu \mathrm{m}$ dominated in terms of biomass (> $50 \%$ of Chlorophyll a) with densities of up to $1.6 \times 10^{4}$ cells $\mathrm{L}^{-1}$, which is approximately 0.6 times higher than observed for early summer in recent years. Additionally, our results confirm a previously observed phenomenon whereby large-size phytoplankton $(>80 \mu \mathrm{m})$, especially pennate diatoms, are replaced by mid-size centric diatoms $(10-80 \mu \mathrm{m})$, such as Thalassiosira spp., and small dinoflagellates (e.g. Prorocentrum antarcticum) during warmer early summers.
\end{abstract}

Keywords: Admiralty Bay, Antarctic coastal zone, Phytoplankton biomass, Size-fraction structure.

\section{INTRODUCTION}

Since 1950, especially during the last two decades, the marine ecosystem along the western continental shelf of the Antarctic Peninsula (WAP) has undergone temperature increasing (Ducklow et al., 2007). One of the consequences is the replacing in all trophic levels of large phytoplankton (e.g. diatoms) and sea ice-dependent zooplankton (e.g. Antarctic krill) by small phytoplankton (flagellates) and ice-avoiding zooplankton (e.g. salps) (Loeb et al., 1997; Moline et al., 2004; Montes-Hugo, 2009; Flores et al., 2012; Ducklow et al., 2013). Studies of nearshore Antarctic phytoplankton are relatively scarce because of the organism's apparent low contribution to the total primary production of the Southern Ocean (El-Sayed \& Fryxell, 1993).

Located on King George Island, Admiralty Bay (AB) was designated as an Antarctic Specially Managed Area (ASMA no.1) by the Antarctic Treaty System Consultative Meeting in 1996 (ATCM XXVIII, 2005 ) to control the impact of activities from countries operating in the area. Since human occupation has increased in recent years (Montone et al., 2013), the island can also be considered as a field laboratory to study the effects of climate change and human distur- bances. The phytoplankton community of Admiralty Bay showed a decline in diatom contribution during the 1990's to 2000's in relation to those observed in the continental shelf region (Kopczynska, 2008; Lange et al., 2014).

Different monitoring projects are being developed in Admiralty Bay under the Brazilian Antarctic Program (PROANTAR) to study marine ecosystem processes and the effects of natural and anthropogenic impacts. Monitoring of the composition and biomass of planktonic microorganisms began in 2002 to gain a long-term perspective of possible inter-annual changes. In 2009, the analysis of the size and trophic structure of the plankton community was implemented, revealing that organisms belonging to the small size class $(<10 \mu \mathrm{m})$ became dominant in Admiralty Bay, both in terms of cell density and Chlorophyll a biomass, with a high contribution of dinoflagellates to this planktonic fraction (Tenenbaum et al., 2011).

This study reveals the size-structure $(0.2$ to $400 \mu \mathrm{m})$, total Chlorophyll a biomass and taxonomic composition (of the fraction larger than $10 \mu \mathrm{m}$ ) of the autotrophic plankton community during early summer 2010. 


\section{MATERIALS AND METHODS}

\section{Study area}

Admiralty Bay $\left(62^{\circ} 03^{\prime}-12^{\prime} \mathrm{S}, 58^{\circ} 18^{\prime}-38^{\prime} \mathrm{W}\right)$, located at King George Island (KGI), is a deep fjordlike embayment with $500 \mathrm{~m}$ maximum depth at its central channel (Rakusa-Suszczewski et al., 1993). The waters from the bay mix with the deep oceanic waters from Bellingshausen and Weddell Seas at its southern opening, which connects to the Bransfield Strait (Lipski, 1987). Deep currents generated by tides, frequent upwellings, vertical mixing of the entire water column and current velocities of $30-100 \mathrm{~cm} \mathrm{~s}^{-1}$ in the 0-100 m surface stratum are characteristic of the bay (Rakusa-Suszczewski, 1993).

\section{Sampling}

The analyses of plankton fractions ( 0.2 to 400 $\mu \mathrm{m}$ ) and Chlorophyll a (Chl.a) concentration were performed from water samples collected with a $5 \mathrm{~L}$ Niskin bottle in three depths (on the surface, in the middle of the water column and approximately $30 \mathrm{~m}$ deep - near the bottom) at five stations in December 2010. The Admiralty Bay location and the position of the sampling stations (Comandante Ferraz-CF, Botany Point - BP, Machu Picchu - MP, Point Thomas - PT, Arctowski AR) are shown in Figure 1.

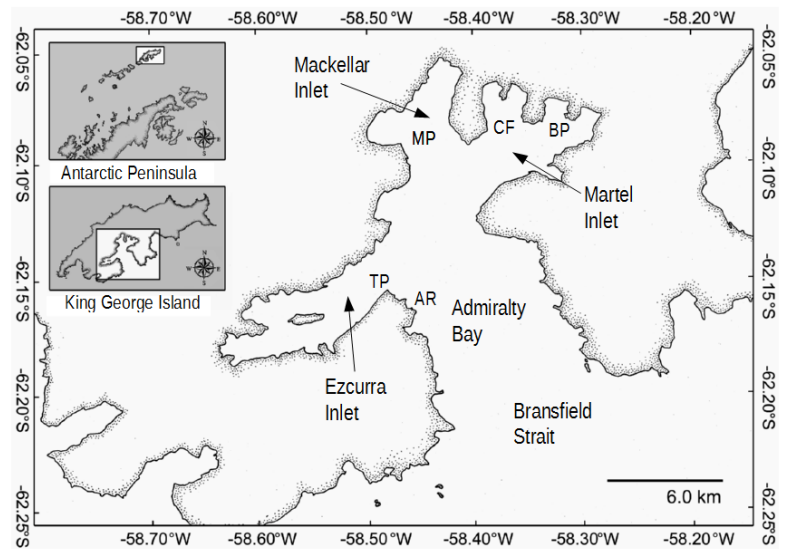

Figure 1 - Map of the Admiralty Bay (King George Island, Antartic Peninsula) with the sampling sites positions: Comandante Ferraz (CF), Botany Point (BP), Machu Picchu (MP), Point Thomas (TP), Arctowski (AR). Adapted from Moura (2009).

Temperature was measured in situ using a Season Mini ${ }^{\circ}$ sensor. Salinity and dissolved inorganic nutrients (nitrite, nitrate, phosphate and silicate) were analyzed by the Laboratório de Química Orgânica Marinha (LabQOM), Instituto Oceanográfico da Universidade de São Paulo (Marine Organic Chemistry Laboratory of the Oceanographic Institute of the University of São Paulo, Brazil) following Grasshoff et al. (1983).

\section{Plankton analyses}

For pico- $(<2 \mu \mathrm{m})$ and ultra $(2-10 \mu \mathrm{m})$ plankton evaluation, $250 \mathrm{~mL}$ aliquots were collected, fixed with $0.22 \mu \mathrm{m}$-filtered $2 \%$ glutaraldehyde (final concentration) and kept in the dark at $4^{\circ} \mathrm{C}$ until laboratory analysis. Sub-samples of $5 \mathrm{~mL}$ (picoplankton) and $30 \mathrm{~mL}$ (ultraplankton) were stained with $0.01 \mu \mathrm{g} \mathrm{L}^{-1}$ DAPI (4',6-diamidino-2-phenylindole) (Martinussen \& Thingstad, 1991) for 10 minutes, filtered through $0.22 \mu \mathrm{m}$ (picoplankton) and $1.0 \mu \mathrm{m}$ (ultraplankton) polycarbonate black membrane filters (Poretics $₫$ ) and mounted on microscope slides between layers of immersion oil. Slides were stored at $-20^{\circ} \mathrm{C}$. Analyses were performed using an Olympus $B \times 51 \AA$ epifluorescence microscope with 1,000 x magnification. Autotrophs were counted by autofluorescence using a blue filter combination (U-MSWB2; $\lambda_{\mathrm{ex}}=420-440$ $\mathrm{nm})$. For the mid- $(>10-80 \mu \mathrm{m})$ and large $(>80-400$ $\mu \mathrm{m}$ ) size fraction (nano+microplankton) analyses, 2.0 $\mathrm{L}$ aliquots were fixed with $2 \%$ buffered formaldehyde (final concentration) and kept in the dark immediately after sampling to guarantee maintenance of pigment fluorescence. For a more detailed trophic approach (Opalinski et al., 1997), the mid-large cells were also separated in size-fractions: $10-30 \mu \mathrm{m}, 31-80 \mu \mathrm{m}$, and $>80 \mu \mathrm{m}$. At the laboratory, samples were analyzed using the settling technique (Utermöhl, 1958), where cells were allowed to settle in $50-100 \mathrm{~mL}$ chambers for 48-72 $\mathrm{h}$ depending upon cell concentration, using an inverted Olympus ${ }^{\circledR}$ IX70 microscope equipped with phase contrast. Organisms larger than $10 \mu \mathrm{m}$ were analyzed in the whole counting chamber at a magnification of 200x. A higher magnification (400x) was used to identify the smallest taxa. Differential interference contrast (DIC) was also used to facilitate the identification of diatoms. Species identification was based on the following literature: Balech (1975), Medlin \& Priddle (1990), Round et al. (1990), Scott \& Marchant (2005), Al-Handal \& Wulff (2008). At least 10 specimens of each taxon were measured for cell maximum linear dimension (MLD) calculations with the Olympus $₫$ Cell-D software.

To determine Chlorophyll a concentration, 500 $\mathrm{mL}$ seawater was filtered through GF/F Whatman filters ( $\varnothing 47 \mathrm{~mm}$ ), which were then placed into $1.2 \mathrm{~mL}$ cryotubes and immediately snap-frozen in liquid nitrogen $\left(-196^{\circ} \mathrm{C}\right)$ and stored at $-80^{\circ} \mathrm{C}$. Pigment extraction was done by adding $90 \%$ acetone into the cryotubes and incubating for $12 \mathrm{~h}$ at $4^{\circ} \mathrm{C}$. The fluorescence properties of the acetone extracts were measured with a Varian Cary Eclipse (Agilent, USA) spectrofluorimeter. Concentrations of Chl.a were assessed with a modified version of Neveux and Lantoine's (1993) method, described by Vanzan et al. (2015). Data acquisition was performed by recording the fluorescence excitation 
spectra from 390 to $480 \mathrm{~nm}$ ( $3 \mathrm{~nm}$ increments) and emission spectra from 615 to $715 \mathrm{~nm}$ ( $2 \mathrm{~nm}$ intervals).

For statistical analyses, the cell density data set was transformed using $\log 10(x+1)$ to normalize the distributions and eliminate zero values. The Pearson's correlation coefficient between biological and environmental variables was calculated using the Statistica ${ }^{\circledR}$ v.7.0 software.

\section{RESULTS}

Water temperature showed relatively high variation $\left(0.13-0.73^{\circ} \mathrm{C}\right)$ among sampling points and depth, registering a decrease with depth at CF, TP and
AR, while an inverse pattern was observed at BP and MP (Fig. 2a). Salinity did not vary significantly (33.90 - 34.35), but showed a tendency of increasing with depth, especially at MP (Fig. 2b). Chl.a concentration was on average $0.54 \pm 0.12 \mu \mathrm{g} \mathrm{L}^{-1}$. The maximum Chl.a value $\left(0.84 \mu \mathrm{g} \mathrm{L}^{-1}\right)$ was observed on the surface of BP (Fig 2c). The mid-large size fractions (>10 $\mu \mathrm{m})$ represented on average more than $50 \%$ of the total Chl.a in all sampling stations during the studied period, as described by Tenório et al. (2013).

Autotrophic plankton exhibited cell density values mainly in the order of $10^{7}$ cells $\mathrm{L}^{-1}$. Picoplankton maximum cell density $\left(2.2 \times 10^{7}\right.$ cells $\left.\mathrm{L}^{-1}\right)$ was observed in the mid-water column of TP (Fig. 2d). The small planktonic autotrophs were numerically dominant
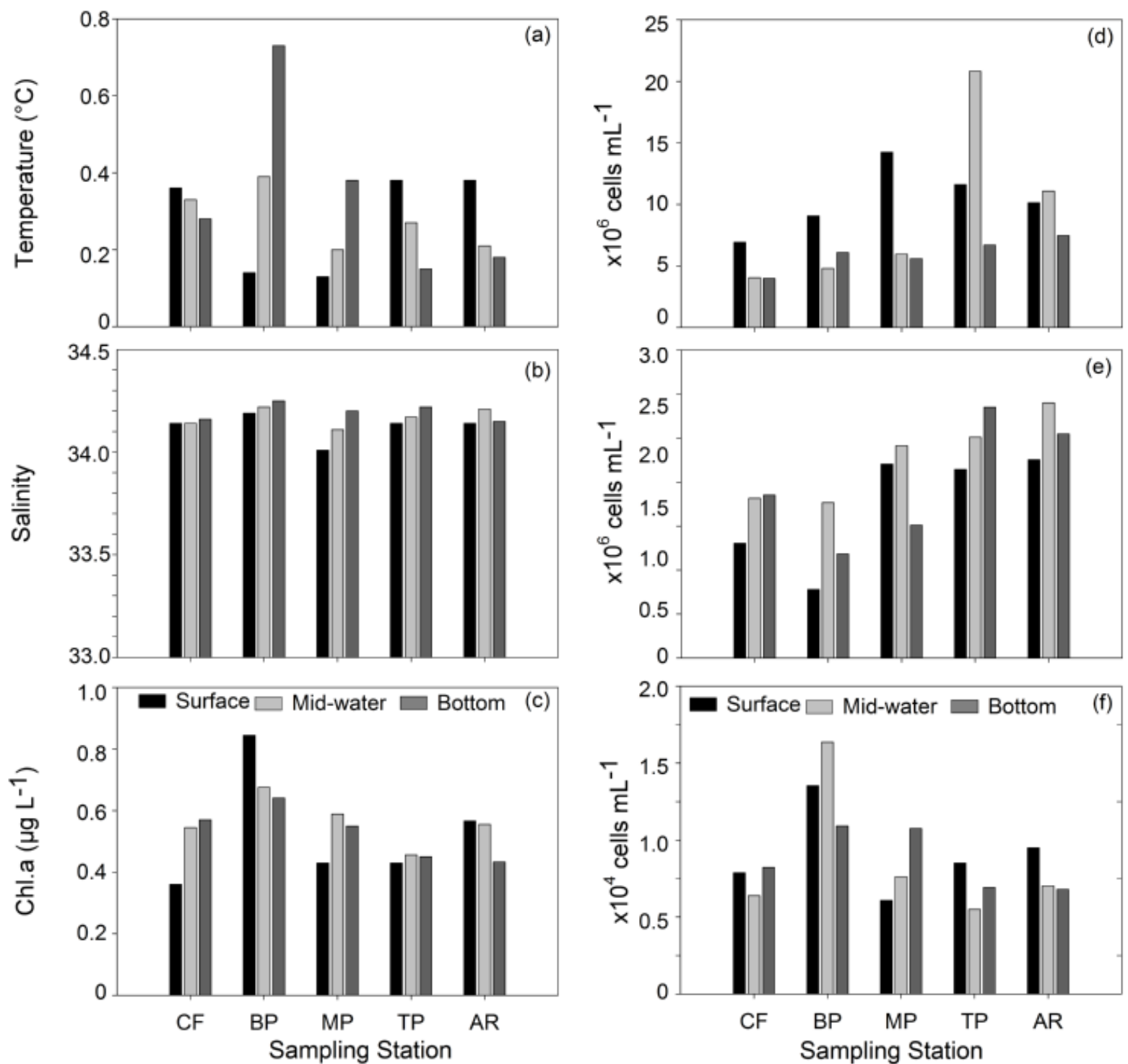

Figure 2: a) temperature $\left({ }^{\circ} \mathrm{C}\right)$; b) salinity; c) total chlorophyll a concentrations $\left(\mu \mathrm{g} \mathrm{L}^{-1}\right)$; d) picoplankton $(0.2-2.0 \mu \mathrm{m})$ cell density $\left(\right.$ cells $\left.\mathrm{L}^{-1}\right)$; e) ultraplankton $(2-10 \mu \mathrm{m})$ cell density (cells $\left.\mathrm{L}^{-1}\right)$; f) large size autotrophic plankton $(>10 \mu \mathrm{m})$ cell density (cells $\left.\mathrm{L}^{-1}\right)$, at different depths and sample sites during the December 2010 survey. 
(>99\%), showing average densities of $8.2 \times 10^{6}$ cells $\mathrm{L}^{-1}$ for picoplankton $(<2 \mu \mathrm{m})$ and $1.9-4.3 \times 10^{6}$ cells $\mathrm{L}^{-1}$ for ultraplankton $(2-10 \mu \mathrm{m})$ (Figs. $2 \mathrm{~d}$ and e). Spatially, densities generally decreased with depth, which occurred from the entrance of Admiralty Bay (AR-TP) to the Martel Inlet (CF-BP). We registered abundances of $10^{3}-10^{4}$ cells $L-1$ for the mid-large size cells, with a maximum value of $1.6 \times 10^{4}$ cells $L^{-1}$ observed at $B P$ (Fig. 2f), where higher temperatures were recorded. This size-fraction showed a positive correlation with Chlorophyll a concentration $(r=0.77, p<0.05)$. The $10-30 \mu \mathrm{m}$ and $31-80 \mu \mathrm{m}$ size-fractions represented on average $44-55 \%$ of the mid- and large size cells for all sampling points and depths (Fig. 3).

A taxonomic composition analysis was performed only for the mid-large fraction, and 57 taxa were identified, distributed in three taxonomic Classes:
Bacillariophyceae (40 taxa), Dinophyceae (15 taxa) and Coccolithophyceae (2 taxa) (Table 1). Centric diatoms were represented by 12 taxa and had predominantly mid-large cell density (68\% of contribution), mainly Thalassiosira anguste-lineata. Pennate diatoms with a raphe (raphids) contributed only with $3.5 \%$ of the total density, but were represented by 21 taxa. Another 7 taxa were described for the pennate diatoms without a raphe (araphids), which contributed with $1.3 \%$ of the density. Armored forms were more abundant among dinoflagellates, representing $15.4 \%$ of mid-large cell density, and were represented by 7 taxa, especially Prorocentrum of antarcticum. Among unarmored dinoflagellates, 8 taxa were identified, contributing with $\sim 11 \%$ of the total density. Coccolithophorids comprised only $\sim 1 \%$ of cell density of the size-fraction $>10 \mu \mathrm{m}$.
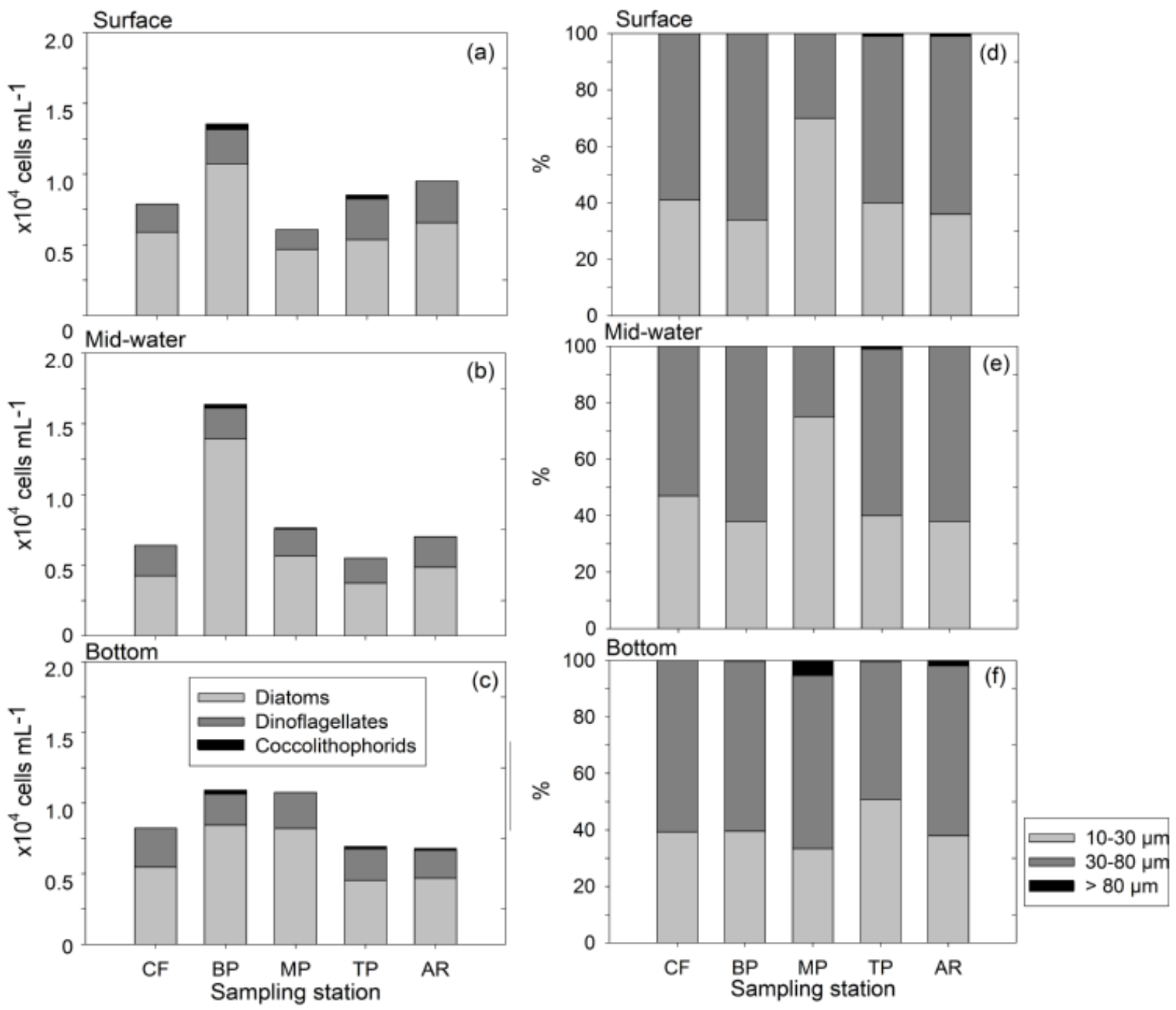

Figure 3: $a, b$ and c) contribution of main groups to large size autotrophic plankton ( $>10 \mu \mathrm{m})$; $d$, e and f) size-structure of the large size autotrophic plankton (> $10 \mu \mathrm{m})$, at different depths and sample sites during the December 2010 survey. 
Table 1: List of taxa observed at the five sampling sites. Taxonomic groups: CD - Centric diatoms; PDR - Pennate diatoms with a raphe (raphids); PDA - Pennate diatoms without a raphe (araphids); AD - Armored dinoflagellates; UD - Unarmored dinoflagellates; CO Coccolithophorids. MLD - maximum linear dimension.

\begin{tabular}{|c|c|c|c|c|c|c|c|}
\hline Taxa and Taxonomic group & & $\begin{array}{l}\text { MLD } \\
(\mu \mathrm{m})\end{array}$ & $\mathrm{CF}$ & BP & MP & TP & AR \\
\hline Actinocyclus actinochilus (Ehrenberg) Simonsen & $C D$ & 28.5 & & & $\mathrm{x}$ & & \\
\hline Actinoptychus senarius (Ehrenberg) Ehrenberg & $C D$ & 30 & & $\mathrm{x}$ & & $\mathrm{x}$ & $x$ \\
\hline Chaetoceros spp. Ehrenberg & $C D$ & 13.5 & & & $x$ & & \\
\hline Coscinodiscus asteromphalus Ehrenberg & $\mathrm{CD}$ & 60 & $\mathrm{x}$ & $\mathrm{x}$ & & & \\
\hline Eucampia antarctica (Castracane) Manguin & $C D$ & 20 & & & $x$ & & \\
\hline Leptocylindrus mediterraneus (Peragallo) Hasle & $C D$ & 50 & & & & $x$ & \\
\hline Odontella aurita (Lyngbye) Agardh & $C D$ & 27.5 & & & $x$ & $x$ & \\
\hline Odontella weissflogii (Grunow) Grunow & $C D$ & 60 & & & $x$ & & \\
\hline Rhizosolenia cf hebetata Bailey & $C D$ & 392 & & & $x$ & & $\mathrm{x}$ \\
\hline Thalassiosira anguste-lineata (Schmidt) Fryxell \& Hasle & $C D$ & 32.5 & & & & & \\
\hline Thalassiosira antarctica Comber & $C D$ & 70 & $x$ & $x$ & $\mathrm{x}$ & $\mathrm{x}$ & $\mathrm{x}$ \\
\hline Thalassiosira spp. Cleve & $C D$ & 20 & & & & & \\
\hline Achnanthes brevipes var. intermedia (Kützing) Cleve & PDR & 40 & $\mathrm{x}$ & & $\mathrm{x}$ & $\mathrm{x}$ & \\
\hline Amphora racovitzae Van Heurck & PDR & 40 & & & & $x$ & $\mathrm{x}$ \\
\hline Cocconeis costata (Gregory) Cleve & PDR & 32.5 & $\mathrm{x}$ & & $\mathrm{x}$ & $x$ & $x$ \\
\hline Cocconeis schuettii van Heurck & PDR & 50 & & & & & $x$ \\
\hline Cocconeis spp. Ehrenberg & PDR & 16 & & & & $\mathrm{x}$ & \\
\hline Cylindrotheca closterium (Ehrenberg) Lewin \& Reimann & PDR & 105 & $\mathrm{x}$ & & & & \\
\hline Fragilariopsis kerguelensis (O'Meara) Hustedt & PDR & 26.5 & & $\mathrm{x}$ & & $\mathrm{x}$ & \\
\hline Fragilariopsis ritscheri Hustedt & $P D R$ & 16.5 & & & $x$ & & \\
\hline Gomphonema spp. Ehrenberg & PDR & 30 & $\mathrm{x}$ & & & & \\
\hline Manguinea fusiformis (Manguin) Paddock & PDR & 95 & & & & $\mathrm{x}$ & \\
\hline Manguinea spp. Paddock & PDR & 80 & $\mathrm{x}$ & & & & \\
\hline Navicula directa (Smith) Ralfs & PDR & 53.3 & & & & & $x$ \\
\hline Navicula directa (Smith) Ralfs & PDR & 137 & & & & $x$ & $x$ \\
\hline Navicula glaciei Van Heurck & PDR & 27.5 & $x$ & & & & $x$ \\
\hline Navicula spp. Bory de Saint-Vincent & PDR & 34.5 & $x$ & & & $\mathrm{x}$ & $x$ \\
\hline Navicula spp. Bory de Saint-Vincent & PDR & 130 & $x$ & & & & \\
\hline Navicula vanhoeffenii Gran & PDR & 25 & & & $x$ & & \\
\hline Nitzschia lecointei Van Heurck & PDR & 70 & & $\mathrm{x}$ & $x$ & $\mathrm{x}$ & $x$ \\
\hline Nitzschia lecointei Van Heurck & PDR & 110 & & $x$ & & $x$ & \\
\hline Nitzschia spp. Hassall & PDR & 25 & $x$ & & $x$ & $x$ & $x$ \\
\hline Nitzschia spp. Hassall & PDR & 110 & & & & & $x$ \\
\hline Pleurosigma spp. Smith & PDR & 175 & & $x$ & & & \\
\hline Pseudogomphonema kamtschaticum (Grunow) Medlin & PDR & 40 & $x$ & & $\mathrm{x}$ & $\mathrm{x}$ & \\
\hline Pseudogomphonema spp. Medlin & PDR & 30.5 & $x$ & & & $x$ & \\
\hline Pseudo-nitzschia heimii Manguin & PDR & 70 & & $\mathrm{x}$ & & & \\
\hline Fragilaria islandica Grunow & PDA & 60 & $\mathrm{x}$ & & & $\mathrm{x}$ & \\
\hline Fragilaria spp. Lyngbye & PDA & 20 & & & $\mathrm{x}$ & $x$ & $x$ \\
\hline
\end{tabular}




\begin{tabular}{|c|c|c|c|c|c|c|c|}
\hline Taxa and Taxonomic group & & $\begin{array}{l}\text { MLD } \\
(\mu \mathrm{m})\end{array}$ & $\mathrm{CF}$ & $\mathrm{BP}$ & MP & TP & $A R$ \\
\hline Grammatophora spp. Ehrenberg & PDA & 50 & $x$ & & $x$ & & \\
\hline Licmophora gracilis (Ehrenberg) Grunow & PDA & 14 & $x$ & & & & \\
\hline Licmophora grandis (Kützing) Grunow & PDA & 75 & & & $\mathrm{x}$ & & $\mathrm{x}$ \\
\hline Licmophora grandis (Kützing) Grunow & PDA & 107 & & $\mathrm{x}$ & $x$ & $\mathrm{x}$ & \\
\hline Licmophora spp. Agardh & PDA & 80 & $\mathrm{x}$ & & & & \\
\hline Thalassiothrix antarctica Schimper \& Karsten & PDA & 350 & & & $\mathrm{x}$ & $\mathrm{x}$ & \\
\hline Amphidinium hadai Balech & UD & 32.2 & & $x$ & $x$ & $x$ & $x$ \\
\hline Amphidinium spp. Claperède \& Lachmann & UD & 32.5 & & $x$ & & & \\
\hline Gymnodinium flavum Kofoid \& Swezy & UD & 37.5 & $x$ & $x$ & & & \\
\hline Gymnodinium guttula Balech & UD & 30.5 & $x$ & $x$ & $x$ & $x$ & $x$ \\
\hline Gymnodinium soyai Hada & UD & 29 & $x$ & $x$ & $x$ & $x$ & $\mathrm{x}$ \\
\hline Gymnodinium spp. Stein & UD & 37.5 & $x$ & $x$ & $\mathrm{x}$ & $x$ & $x$ \\
\hline Gyrodinium glaciale Hada & UD & 28 & $x$ & $x$ & $x$ & $x$ & $\mathrm{x}$ \\
\hline Gyrodinium spp. Kofoid \& Swezy & UD & 28 & $x$ & $x$ & $x$ & $x$ & $x$ \\
\hline Alexandrium tamarense (Lebour) Balech & $A D$ & 22.5 & $x$ & $\mathrm{x}$ & & $\mathrm{x}$ & $\mathrm{x}$ \\
\hline Amylax spp. Meunier & $A D$ & 26 & $x$ & & $\mathrm{x}$ & $\mathrm{x}$ & \\
\hline Gonyaulax spp. Diesing & $A D$ & 25 & & & & & $\mathrm{x}$ \\
\hline Prorocentrum antarcticum (Hada) Balech & $A D$ & 15 & & & & & \\
\hline Prorocentrum compressum (J.W.Bailey) Abé ex Dodge & $A D$ & 27 & & $\mathrm{x}$ & & $\mathrm{x}$ & $\mathrm{x}$ \\
\hline Prorocentrum compressum (J.W.Bailey) Abé ex Dodge & $A D$ & 55 & & $\mathrm{x}$ & & $\mathrm{x}$ & \\
\hline Prorocentrum spp. Ehrenberg & $A D$ & 27.5 & & $\mathrm{x}$ & & & $\mathrm{x}$ \\
\hline Protoperidinium cf defectum (Balech) Balech & $A D$ & 29.5 & & $x$ & & $x$ & $\mathrm{x}$ \\
\hline Phaeocystis antarctica Karsten & $\mathrm{CO}$ & 5 & & & & $x$ & \\
\hline Unidentified coccolithophorids & $\mathrm{CO}$ & 12 & & $x$ & $x$ & $x$ & $\mathrm{x}$ \\
\hline
\end{tabular}

$10-20 \% ; . . .20-40 \% ; \square 40 \%$

\section{DISCUSSION}

Early summer of $2010 / 2011$ was characterized by positive water temperatures at $A B\left(>0.3^{\circ} \mathrm{C}\right)$, which were on average higher than the temperature described for December during the decades of 1990s and 2000s $\left(<0.0^{\circ} \mathrm{C}\right)$ (Lange et al., 2007, Kopczynska, 2008; Tenenbaum et al., 2011; Lange et al., 2014). This observation is in line with the raising summer water temperatures observed for $\mathrm{KGI}$ coastal waters during the last two decades (Schloss et al., 2012; Lange et al., 2014; Schloss et al., 2014). In a long-term study, Boyce et al. (2010) reported that phytoplankton biomass in the global ocean, including Arctic and Antarctic regions, declined by $1 \%$, which strongly correlates with the increase in sea surface temperatures over the past century. On the other hand, exceptionally cold summers, such as that of 2009/2010, promoted summer phytoplankton blooms in KGI coastal waters (Costa \& Agosta, 2012; Schloss et al., 2014). In Polar regions, the rise in the incident radiation and temperature promote an increase in both terrestrial and sea ice melting, with positive (e.g. increasing fertilization, organism inoculation and water column stratification) and negative (e.g. increasing turbidity and attenuating light) effects on the phytoplankton community (Martin et al., 1991; Brandini \& Rebello, 1994; Nedzarek and Rakusa- Suszczewski 2004; Lannuzel et al., 2007; Becquevort et al., 2009; Lannuzel et al., 2013). In the present study we observed higher midand large size phytoplankton cell densities $\left(10^{3}-10^{4}\right.$ cells $\mathrm{L}^{-1}$ ) than those observed for the same region 
in previous studies conducted during the austral summers of 2002/03, 2003/04, 2007/08, 2008/09 and 2009/2010 (Tenenbaum et al., 2011; Lange et al.,

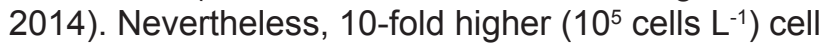
densities were commonly observed at Admiralty Bay during the decades of the 1970s, 1980s and 1990s (i.e. Kopczynska, 2008), confirming that there is a decrease in microphytoplankton biomass at $A B$. The high water temperature registered during December 2010, responsible for earlier and enhanced melting processes, probably led to the observed dominance of small size phytoplankton in terms of density among the phytoplankton community. This dominance led to a shift on the zooplankton composition, from Antarctic krill to salps, also having consequences on higher trophic levels (Moline et al., 2004). As observed in a previous study conducted during the late summer 2009/2010 (Tenenbaum et al., 2011), the small cells represented the main portion of the autotrophic plankton community in Admiralty Bay. Among the mid-size phytoplankton, the centric diatom Thalassiosira anguste-lineata (MDL $\sim 32.5 \mu \mathrm{m}$ ) was responsible for the highest abundances, as observed by Lange et al. (2014) during the summer 2003/04 and Schloss et al. (2014) in January 2010. This diatom dominance is characteristic of $A B$ microphytoplankton. Notwithstanding, previous studies have reported that pennate diatoms were dominant in early summer as a result of resuspension from the bottom, while epiphytic or epontic diatoms and large $(>100 \mu \mathrm{m})$ centric diatoms were associated with ice melting (Kopczynska, 2008; Lange et al., 2014). The mid-size centric diatoms, such as the T. angustelineata, have been described as the most palatable species to krill, in contrast to diatoms greater than 70 $\mu \mathrm{m}$ (Opalinskiet et al., 1997, Ligowski, 2000).

\section{CONCLUSION}

The current study presents the detailed taxonomic composition of the autotrophic plankton larger than $10 \mu \mathrm{m}$ and shows a shift in phytoplanktonic community due to changes of water temperature in Admiralty Bay, Antarctic Peninsula at the early austral summer 2010. Importantly, we report here the increasing contribution of small planktonic autotrophs $(<10 \mu \mathrm{m})$ in terms of abundance and the replacing of large-size phytoplankton ( $>80 \mu \mathrm{m}$ ) by mid-size centric diatoms $(10-80 \mu \mathrm{m})$ during warmer early summers. Further studies on phytoplankton size structure and activity are necessary to better understand the importance of each phytoplankton compound to primary production and trophic webs in West Antarctic Peninsula coastal areas.

\section{ACKNOWLEDGMENTS}

This work integrates the National Institute of Science and Technology Antarctic Environmental Research (INCT-APA), which receives scientific and financial support from the National Council for Research and Development (CNPq process: $n^{\circ} 574018 / 2008-5$ ) and the Research Support Foundation of the State of Rio de Janeiro (FAPERJ $n^{\circ}$ E-16/170.023/2008). The authors are also grateful for the support of the Brazilian Ministries of Science, Technology and Innovation (MCTI), and of Environment (MMA), the Inter-Ministry Commission for Sea Resources (CIRM), the Brazilian Navy (MB). The Marine Organic Chemical Laboratory of the Oceanographic Institute of Sao Paulo University (LabQOM-IOUSP) for physical and chemical analysis. Moura RB for the figure of the study area (Fig. 1). M. Vanzan thanks CNPq for the Technological and Industrial Development fellowship under process $n^{\circ}$ 385083/2013-0. J.J. Barrera-Alba thanks CNPq for the post-doctoral fellowship under process $n^{\circ}$ 151651/2010-8. M.M.B. Tenório thanks FAPERJ/ CAPES for the post-doctoral fellowship under process $n^{\circ}$ E-26/102.015/2009.

\section{REFERENCES}

Al-Handal, A.Y. \& Wulff, A. 2008. Marine benthic diatoms from Potter Cove, King George Island, Antarctica. Botanica Marina, 51, 51-68.

ATCM XXVIII 2005. Review of the Admiralty Bay Antarctic specially managed area management plan (ASMA n 1), 31 pp.

Balech, E. 1975. Clave Ilustrada de Dinoflagelados Antarticos. Instituto Antartico Argentino, Direccion Nacional del Antartico, Buenos Aires, 98 pp.

Boyce, D.G., Lewis, M.R. \& Worm, B. 2010. Global phytoplankton decline over the past century. Nature, 466: 591-596, doi:10.1038/nature09268

Costa, A. \& Agosta, E. 2012. South Pacific quasistationary waves and anomalously cold summers in northernmost Antarctic Peninsula. Geoacta, 37: 73-82.

Delille D.; Gleizon, F. \& Delille, B. 2007. Spatial and temporal variations of bacteria and phytoplankton in a subAntarctic coastal area (Kerguelen Archipelago). J. Mar. Sys., 68(3-4): 366-380.

Ducklow, H.W.; Baker, K.; Martinson, D.G., Quetin, L.B.; Ross, R.M.; Smith, R.C.; Stammerjohn, S.E.; Vernet, M. \& Fraser, W. 2007. Marine pelagic ecosystems: the West Antarctic Peninsula Philos. Trans. R. Soc. London Ser. B, 362: 67-94.

Ducklow, H.W., W.R. Fraser, M.P. Meredith, S.E. Stammerjohn, S.C. Doney, D.G. Martinson, S.F., 
Sailley, O.M. Schofield, D.K. Steinberg, H.J. Venables, \& Amsler, C.D. 2013. West Antarctic Peninsula: An ice-dependent coastal marine ecosystem in transition. Oceanography 26(3):190203, http://dx.doi.org/10.5670/oceanog.2013.62

El-Sayed, S. Z. \& Fryxell, G. A. 1993. Phytoplankton. In Friedmann. E.I., ed. Antarctic microbiology. New York: Wiley-Liss. 65-122.

Flores, H.; Atkinson, A.; Kawaguchi, S.; Krafft, B.A.; Milinevsky, G.; Nicol, S.; Reiss, C.; Tarling, G.A.; Werner, R.; Rebolledo, E.B.; Cirelli, V.; Cuzin-Roudy, J.; Fielding, S.; Groeneveld, J.J.; Haraldsson, M.; Lombana, A.; Marschoff, E.; Meyer, B.; Pakhomov, E.A.; Rombolá, E.; Schmidt, K.; Siegel, V.; Teschke, M.; Tonkes, H.; Toullec, J.Y.; Trathan, P. N.;Tremblay, N.; van de Putte, A.P.; van Franeker, J.A. \& Werner, T. 2012. Impact of climate change on Antarctic krill. Marine Ecology Progress Series, 458: 1-19.

Hasle, G.R. 1972. The distribution of Nitzschia seriata Cleve and allied species. In: SIMONSEN, R. (Ed.) 1972. First Symposium on Recent and Fossil Marine Diatoms: 171-190.

Kopczynska, E.E. 2008. Phytoplankton variability in Admiralty Bay, King George Island, South Shetland Islands: six years of monitoring. Polish Polar Research, 29(2): 117-139.

Lange, P.K.; Tenenbaum, D.R.; Braga, E.S.B. \& Campos, L.S. 2007. Microphytoplankton assemblages in shallow waters at Admiralty Bay (King George Island, Antarctica) during the summer 2002-2003. Polar Biology, 30: 1483-1492.

Lange, P.K., Tenenbaum, D.R., Tavano, V.M., Paranhos, R. \&Campos, L.S. 2014. Shifts in microphytoplankton species and cell size at Admiralty Bay, Antarctica. Antarctic Science, doi:10.1017/S0954102014000571

Loeb, V.J.; Siegel V.; Holm-Hansen, O.; Hewitt, R.; Fraser, W.; Trivelpiece, W.; Trivelpiece, S. 1997. Effects of sea-ice extent and krill or salp dominance on the Antarctic food web. Nature, 387:897-900.

Martinussen, I. \& Thingstad. T.F. 1991. A simple doublestaining method for enumeration of autotrophic and heterotrophic nano- and picoplankton. Mar. Microb. Food Webs, 5: 5-11.

Medlin, L.K., \& Priddle, J. 1990. Introduction. Polar Marine Diatoms. British Antarctic Survey, Natural Environment Research Council.

Moline, M.A.; Claustre, H.; Frazer, T.K.; Schofield, O. \& Vernet, M. 2004. Alteration of the food web along the Antarctic Peninsula in response to a regional warming trend. Global Change Biology (2004) 10, 1973-1980, doi: 10.1111/j.1365-2486.2004.00825.x Montes-Hugo, M.; Doney, S.C.; Ducklow, H.W.; Fraser, W.; Martinson, D.; Stammerjohn, S.E. \& Schofield,
O. 2009. Recent Changes in Phytoplankton Communities Associated with Rapid Regional Climate Change Along the Western Antarctic Peninsula. Science, 323: 1470-1473.

Montone, R.C.; Alvarez, C.E.; Bícego, M.C.; Braga, E.S.; Brito, T.A.S. ; Campos, L.S.; Fontes, R.F.C.; Castro, B.M.; Corbisier, T.N.; Evangelista, H.; Francelino, M.; Gomes, V.; Ito, R.G.; Lavrado, H.P.; Leme, N.P.; Mahiques, M.M.; Martins, C.C.; Nakayama, C.R.; Ngan, P.V.; Pellizari, V.H.; Pereira, A.B.; Petti, M.A.V. ; Sander, M.; Schaefer, C.E.G.R.; Weber, R.R. 2013. Environmental Assessment of Admiralty Bay, King George Island, Antarctica. In: Verde, C., di Prisco, G. (Org.). From Pole to Pole. 1ed.: Springer Berlin Heidelberg, v. 2, p. 157-175.

Moura, R.B. 2009. Estudo taxonômico dos Holothuroidea (Echinodermata) das Ilhas Shetland do Sul e do Estreiro de Bransfield, Antártica. Dissertação de Mestrado, Museu Nacional, Universidade Federal do Rio de Janeiro.

Neveux, J. \& Lantoine, F. 1993. Spectrofluorometric assay of chlorophylls and phaeopigments using the least squares approximation technique. Deep-Sea Research I, 40(9): 1747-1765.

Opalinski, K.W.; Maciejewska, K. \& Georgieva, L.V. 1997. Notes on food selection in the Antarctic krill, Euphausia superba. Polar Biology, 17, 350-357.

Rakusa-Suszczewski, S.; Mietus, M. \& Piasecki, J. 1993. Weather and climate. In: Rakusa-Suszczewski S (ed) The maritime coastal ecosystem of Admiralty Bay. Dept. Antarctic Biol, Polish Academy of Science, Warsaw, pp 19-25.

Round, F.E.; Crawford, R.W. \& Mann, D.G. 1990. The Diatoms, Biology \& Morphology of the Genera. Cambridge: Cambridge University Press, 747pp.

Scott, F.J., \& Marchant, H.J. 2005. Antarctic Marine Protists. ABRS, Camberra and Australian Antarctic Division, Hobart, 563 pp.

Schloss, I.R., Abele, D., Moreau, S., Demers, S., Bers, A.V., González, O. \& Ferreyra, G.A. 2012. Response of phytoplankton dynamics to 19year (1991- 2009) climate trends in Potter Cove (Antarctica). Journal Marine Systems, 92: 53-66, doi:10.1016/j.jmarsys.2011.10.006

Schloss, I.R.; Wasilowska, A.; Dumont, D.; Almandoz, G.O.; Hernando, M.P.; Michaud-Tremblay, C.-A.; Saravia, L.; Rzepecki, M.; Monien, P.; Monien, DKopczynska, E.E., Bers, A. V.\& and Ferreyra, G.A. 2014. On the phytoplankton bloom in coastal waters of southern King George Island (Antarctica) in January 2010: An exceptional feature? Limnology \& Oceanography, 59(1): 195-210

Tenenbaum, D.R.; Barrera-Alba, J.J.; Duarte, R.D. \& Tenório, M.B. 2011. Plankton Structure of shallow 
coastal zone at Admiralty Bay, King George Island, West Antarctic Peninsula (WAP): pico, nano and microplankton and chlorophyll biomass. Annual Activity Report 2010, INCT-APA, v.2: 108-114.

Tenório, M.M.B.; Barrera-Alba, J.J. \& Tenenbaum, D.R. 2013. Plankton Structure of the Shallow Coastal Zone at Admiralty Bay, King George Island, West Antarctic Peninsula (Wap): Chlorophyll Biomass and Size-Fractionated Chlorophyll During Austral Summer 2010/2011. Annual Activity Report 2012, INCT-APA v.4: 109-114, 2013.
Utermöhl H., Zur, 1958. Vervollkommung der quantitativen methodik. Mitteilungen der Internationale Vereinigung für Teoretische und Angewandte Limnologie, 9: 1-38.

Vanzan, M.; Barrera-Alba, J.J.; Tenório, M.M.B. \& Tenenbaum, D.R. 2015. Picoplankton and nanoplankton variability in an Antarctic shallow coastal zone (Admiralty Bay) during the austral summer of 2010/2011. Polar Biology (Print), v. 38:1-18, 2015 